believed that pig production could be kept up as an economic proposition, making an appreciable contribution to the national supply of meat and animal fat for human consumption.

\section{Water-Power of the World}

THE United States Geological Survey has attempted a new estimate of the potential and developed waterpower resources of the world. The estimate is based on ordinary medium flow and 100 per cent efficiency. Potential power is based on existing flow and disregards storage except in the case of constructed reservoirs. The estimates for developed power are based on installed capacity of machinery at constructed plants, which averages two or three times the potential power at low flow at the same sites. Thus, for example, the potential power at utilized sites in France amounts to 21 per cent of the total potential power of that country, but in effect amounts to 44 per cent of the theoretical total power resources. With this proviso, it is noted that about ten per cent of the potential water-power of the world is developed. The capacity of the constructed plant in the world at the end of 1936 was 60 million horsepower, or an increase of 160 per cent in sixteen years. The United States show by far the greatest development, but Canada, France, Italy and Japan have high figures, and Norway, Germany, Sweden, Switzerland and the Soviet Union show rising totals.

\section{Biochemistry in India}

THE Society of Biological Chemists, India, publishes a useful review each year of the results of investigations in biochemical subjects which have been carried out in India during the previous twelve months. The current number (Annual Review of Biochemical and Allied Research in India, 7, 1936. Pp. 165. (Bangalore : Society of Biological Chemists, India, 1937.) 3s.) is divided into seventeen sections, of which about two-thirds are devoted to various aspects of agricultural science. Sections are also given to vitamins and hormones, pharmacology and human physiology, pathology and bacteriology. The papers reviewed have, of course, been published in full in other journals, chiefly Indian, but this volume provides a useful summary of work which is not always easily accessible. It is noticeable that the size of the volume has been increased considerably since this review was first published, a tribute to the steady progress research is making in India.

\section{Diseases of Fur Animals}

ThE United States Department of Agriculture, Washington, D.C., in Farmer's Bulletin No. 1777, gives an account of the diseases attacking fur-animals on the farm, together with methods of control. Descriptions are given of distemper, paratyphoid infection and encephalitis of foxes, of hookworm, tapeworm and fluke affections, and of external parasites such as fleas, lice and sarcoptic mange, as well as of nutritional disturbances. Useful information is also given on farm sites and structure, their sanitation and disinfection. The Bulletin should be of value to those engaged in the fur industry in Great Britain.

\section{Fire at Messrs. Flatters and Garnett, Ltd.}

A serious fire occurred on Sunday morning, December 19, at the laboratories of Messrs. Flatters and Garnett, Ltd., the well-known Manchester firm of microscopists. The chemical and microscopical laboratories were completely burnt out, but a con. siderable number of mounted slides were saved. The photographic and lantern slide department was only slightly involved and the new instrument workshop, for manufacturing microscopes, micro-projectors, etc., escaped entirely. All the staff is being retained, and work has already been resumed in temporary laboratories. Stocks of most of the firm's chemical specialities are held at the head office, 309 Oxford Road, Manchester, 13, which is two miles from the laboratories.

\section{Awards of the Institution of Naval Architects}

THE Council of the Institution of Naval Architects has awarded the premium of the Institution for the year 1937 to Mr. R. W. L. Gawn, for his paper "Results of Experiments on Model Screw Propellers with Wide Blades", the Wakeham Prize (1937) to Mr. H. Lackenby, for his paper "Re-analysis of William Froude's Experiments on Surface Friction and their Extension in the Light of Recent Develop. ments", and the Duke of Northumberland Prize (1937) (awarded by the Council of the Institution in connexion with the award of National Certificates in Naval Architecture) to Mr. D. N. Wallace, of the Royal Technical College, Glasgow.

\section{International Federation of Eugenic Organizations}

THE report of the Twelfth Conference of the International Federation of Eugenic Organizations, held at Scheveningen, Holland, in July 1936, has just been issued, and can be obtained from W. P. van Stockum and Zn., N.V., The Hague, Holland, price three Dutch florins. A list of the fifty delegates from twenty countries is followed by twenty-five papers presented at the meetings. The papers range from the classification and inheritance of mental defects to mutations in plants and man, twin studies and the problems of sterilization in Germany, Denmark, Sweden and the United States. The 119 pages end with a report of the Human Heredity Bureau and also reports on the standardization of measurements in anthropometry, physiometry, psychometry and on racial psychiatry.

\section{Fifth International Congress for Experimental Cytology}

THE fifth Congress for Experimental Cytology will be held in Zurich on August 7-12, 1938. The sixteenth International Physiological Congress and the Intermational Veterinarian Congress will be held in Zurich too, on August 14-18 and August 21-25 respectively. The proceedings of the Cytological Congress are not to be divided in sections, but will be organized in the following way : Scientific sessions will take up seven half days; two afternoons are reserved for demonstrations, and during one afternoon there will be an excursion. Special subjects are to be treated at each session, opening with a general 